The Supreme Court Law Review: Ósgoode's Annual Constitutional Cases Conference

\title{
The McLachlin Court and the Charter in 2012
}

Jamie Cameron

Osgoode Hall Law School of York University, jcameron@osgoode.yorku.ca

Follow this and additional works at: https://digitalcommons.osgoode.yorku.ca/sclr

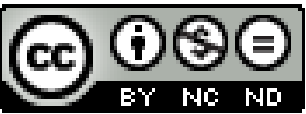

This work is licensed under a Creative Commons Attribution-Noncommercial-No Derivative Works 4.0 License.

\section{Citation Information}

Cameron, Jamie. "The McLachlin Court and the Charter in 2012." The Supreme Court Law Review: Osgoode's Annual Constitutional Cases Conference 63. (2013).

https://digitalcommons.osgoode.yorku.ca/sclr/vol63/iss $1 / 2$ 


\title{
The McLachlin Court and the Charter in 2012
}

\author{
Jamie Cameron*
}

\section{INTRODUCTION}

In 2012 - the year of its 30th anniversary - Canadians learned that the Canadian Charter of Rights and Freedoms ${ }^{1}$ is now more influential abroad than the U.S. Constitution. ${ }^{2}$ Despite that boost, last year's anniversary lacked the celebratory verve of earlier milestones. ${ }^{3}$ The federal government led by Prime Minister Stephen Harper snubbed the occasion, refusing to extend the courtesy of birthday wishes or rehearse the customary platitudes which applaud the virtues of constitutional

* Professor of Law, Osgoode Hall Law School. I thank Holden Sumner (J.D. 2013) and Kendall Grant (J.D. 2015) for their valuable research assistance. I also thank Benjamin Berger and Cara Zwibel for their insightful comments on a draft of the paper.

Part I of the Constitution Act, 1982, being Schedule B to the Canada Act 1982 (U.K.), 1982, c. 11 [hereinafter "Charter"].

2 D. Law \& M. Versteeg, "The Declining Influence of the U.S. Constitution" (2012) 87 N.Y.U. L. Rev. 762 [hereinafter "Law \& Versteeg"], as reported by Adam Liptak in "WWe the People' Loses Appeal with People Around the World" (February 6, 2012), The New York Times online: <http://www.nytimes.com/2012/02/07/us/we-the-people-loses-appeal-with-people-aroundthe-world.html $>$.

In 1987, for example, a postage stamp was issued in honour of the Charter's fifth anniversary. More recently, the 25th anniversary in 2007 featured several conferences and publications; see, e.g., J. Cameron \& J. Stribopoulos, eds., The Charter and Criminal Justice, Twenty-Five Years Later (Markham, ON: LexisNexis Canada, 2008); J.E. Magnet \& B. Adell, eds., The Canadian Charter of Rights and Freedoms After Twenty-Five Years (Markham, ON: LexisNexis Canada, 2009); "The Charter @ 25” (2007) Policy Options, online: Institute for Research on Public Policy" $<$ http://www.irpp.org/en/po/the-charter-25/>. Last year the Constitutional Cases conference celebrated the Charter's 30th anniversary with two volumes of the Supreme Court Law Review: B. Berger \& J. Stribopoulos, eds., Unsettled Legacy: Thirty Years of Criminal Jurisprudence under the Charter (Markham, ON: LexisNexis Canada, 2012) and 57 S.C.L.R. (2d); J. Cameron \& S. Lawrence, eds., Constitutional Cases 2011 (2012), 58 S.C.L.R. (2d) [hereinafter "Constitutional Cases 2011"] (anniversary volume). 
rights belonging to and protecting all Canadians. The prime minister lamely explained that such encomiums were inappropriate in light of Quebec's unresolved objection to patriation and constitutional reform 30 years ago, in $1982{ }^{4}$

A key feature of the Osgoode Hall Law School Constitutional Cases conference, which celebrated its 15 th anniversary last year in 2012, is its annual review of the Supreme Court's jurisprudence. ${ }^{5}$ Quantitative and qualitative in scope, this review has provided the kind of analytical continuity that is especially helpful in understanding the McLachlin Court's response to the Charter over time, from 2000 — the year Beverley McLachlin was appointed Canada's first female Chief Justice - to the present. A historical survey of the review articles since the year 2000 shows that, until recently, the rate of success for Charter claims in the McLachlin Court has been relatively constant at about 45 per cent. ${ }^{6}$ That rate dropped in 2010 and 2011 and for the third year in a row, this year's success rate remains fixed at about 20 per cent. $^{7}$

Meanwhile, the Charter's promises continue to be undermined by the federal government's legislative agenda. Through a variety of measures which have been enacted or are moving through the legislative process, the government has declared that it has little intention of practising evidence-based policymaking, and has also signalled that its lawmaking will not be inhibited by undue solicitude for the protection of rights. This describes the federal government's approach, at present, on issues affecting the rights of the accused, immigrants and refugees, those with mental disorders, and Canadians more generally. ${ }^{8}$

J. Ditchburn, "Constitutional 'Divisions' Keep Harper from Celebrating the Charter", April 16, 2012, The Globe and Mail online: <http://www.theglobeandmail.com/news/politics/ constitutional-divisions-keep-harper-from-celebrating-charter/article4100714/>.

The Constitutional Cases conference was instituted in 1997 to provide annual analysis and commentary on the Supreme Court of Canada's constitutional jurisprudence. Since 2001 the Supreme Court Law Review has published the conference papers annually; see York Digital Journals: $<$ http://pi.library.yorku.ca/ojs/index.php/sclr $>$. Until this year, the annual review paper was under the leadership of Patrick Monahan, a long-time Osgoode colleague and founder of the conference. Monahan accepted an appointment as Deputy Minister of the Ontario Attorney General in fall of 2012. His review articles, which frequently are co-authored, provide quantitative data on the Charter's rate of success in the McLachlin Court. See references, infra. See also P. Monahan, "'In the Public Interest': Understanding the Special Role of the Government Lawyer" in B. Berger, J. Cameron \& S. Lawrence, eds., (2013) 63 S.C.L.R. (2d) [hereinafter "Constitutional Cases 2012"].

See infra, note 21 .

7 See infra text and accompanying footnotes 30 (2011), 31 (2010), and 17 (2012).

8 See, e.g., Bill C-10, Safe Streets and Communities Act, S.C. 2012, c. 1 (omnibus legislation containing nine statutes); Bill C-31, Protecting Canada's Immigration System Act, S.C. 2012, c. 17 (omnibus legislation amending several statutes which deal with immigration and 
In combination, the Court's lessened engagement and the federal government's attitude of indifference create an unhealthy climate for the protection of Charter rights. It may be premature to sound the alarm, as there is nuance in the jurisprudence and, on the longer view, the courts have acquitted themselves well in stepping up to the Charter mandate. Yet it is elementary that rights are fragile, and well known that their protection demands vigilance. As in the past, this year's review provides a quantitative and qualitative analysis of the 2012 constitutional jurisprudence. In doing so, the discussion underlines the Charter's downward trend and poses broader questions about the significance of recent jurisprudential patterns.

The Charter's fluidity over time is sustaining. From that vantage, it might not be concerning that the Charter is momentarily in stall, so long as it can safely be assumed that it will pull out and re-ascend. Pending that momentum shift, forbearance and persistence in urging the Charter onward will have to suffice. Though patience may be rewarded, it is unknown at this point whether the current stall is a passing or more lasting condition. The momentum shift and re-ascent may not happen; if and when it does the Charter's next iteration will likely look quite different.

As this paper shows, these dynamics hint that the next iteration may already be embedding in legal and political culture. It appears, today, that the rights-enforcing energy of the Charter's early years is largely spent, and as that energy wanes, a post-transformative view of the Charter is evolving. That view conceptualizes the Charter as more a middle-ground document than an aspirational instrument of progress. The Court plays a less active role in this iteration, serving more as a yeoman of rights than a leader in thinking deeply about the Charter's promises and how they can be kept. Rights protection is a dutiful but uninspired task in this account and is defined by a quest for compromise and practicality, over and above principle and the commitments it demands. More passive in nature, the yeoman's role glosses, elides and slips around searching questions about the scope and meaning of rights.

If the Charter has been fluid from the start, this iteration-in-the-making presents an unsettling view of rights protection in Canada today. This year's review begins with a survey of the 2012 jurisprudence by the

refugee matters); Bill C-30, Protecting Children from Internet Predators Act (creating telecommunications powers so controversial the "Internet spying bill" was withdrawn); Bill C-54, Not Criminally Responsible Act, 2nd reading May 28, 2013 (amending Part XX.1 of the Criminal Code, R.S.C. 1985, c. C-46). 
numbers, and comments on data that show the Charter trending down for the last three years. From there, the review takes form as a hybrid between the annual reviews of earlier years, and a "foreword" piece that comments thematically — and critically — on the Court's work. Those themes are accessed, in part, through pointed analysis of two key decisions on the Charter's fundamental freedoms in this period: $R$. v. Khawaja $a^{9}$ and Saskatchewan (Human Rights Commission) v. Whatcott. ${ }^{10}$ In turn, that analysis builds a platform for reflections on the Charter's place in our legal and political culture, 30 years later. If it is histrionic to ask whether the Charter still matters - for surely it does - questions about why, how and in what ways are not misplaced at this point in time. ${ }^{11}$

\section{2012: BY THE NUMBERS}

Officially, the McLachlin Court's constitutional output in 2012 was 11 decisions on a docket of 75 cases, 10 of which arose under the Charter and one other under the division of powers. ${ }^{12}$ With two double counting under section 7 and the fundamental freedoms, the Court considered the Charter's legal rights seven times, ${ }^{13}$ addressed its fundamental freedoms

\footnotetext{
9 [2012] S.C.J. No. 69, [2012] 3 S.C.R. 555 (S.C.C.) [hereinafter "Khawaja"].

10 [2013] S.C.J. No. 11, 409 Sask. R. 75 (S.C.C.) [hereinafter "Whatcott"].

11 See H. Arthurs \& B. Arnold, "Does the Charter Matter?" (2005) 11 Rev. Const. Studies 37 (explaining that progress under the Charter has been "modest, halting, non-existent, and, in some cases, negative" and stating that the Charter "does not much matter in the precise sense that it has not ... significantly altered the reality of life in Canada").

On the division of powers, see Tessier Ltée v. Quebec (Commission de la santé et de la sécurité du travail), [2012] S.C.J. No. 23, [2012] 2 S.C.R. 3 (S.C.C.) (upholding provincial jurisdiction over labour relations for stevedoring).

${ }_{13} R$. v. Tse, [2012] S.C.J. No. 16, [2012] 1 S.C.R. 531 (S.C.C.) [hereinafter "Tse"] (s. 8); $R$. v. Bellusci, [2012] S.C.J. No. 44, [2012] 2 S.C.R. 509 (S.C.C.) [hereinafter "Bellusci"] (s. 24(1)); $R$. v. Cole, [2012] S.C.J. No. 53, [2012] 3 S.C.R. 34 (S.C.C.) [hereinafter "Cole"] (ss. 8 and 24(2)); $R$. v. St-Onge Lamoureux, [2012] S.C.J. No. 57, [2012] 3 S.C.R. 187 (S.C.C.) [hereinafter "St-Onge"] (s. 11(d)); R. v. Nedelcu, [2012] S.C.J. No. 59, [2012] 3 S.C.R. 311 (S.C.C.) [hereinafter "Nedelcu"] (s. 13); R. v. Aucoin, [2012] S.C.J. No. 66, [2012] 3 S.C.R. 408 (S.C.C.) [hereinafter "Aucoin"] (ss. 8 and 24(2)); R. v. Khawaja, supra, note 9 (s. 7); R. v. S. (N.), [2012] S.C.J. No. 72, [2012] 3 S.C.R. 726 (S.C.C.) [hereinafter "S. (N.)"] (s. 7). For commentary on the legal rights in this year's volume, see N. Hasan, "Three Theories of "Principles of Fundamental Justice"; A. Klein, "The Arbitrariness in 'Arbitrariness' (And Overbreadth and Disproportionality): Principle and Democracy in Section 7 of the Charter"; H. Stewart, R. v. Khawaja: At the Limits of Fundamental Justice"; D. Stuart, "Vagueness, Inconsistency and Less Respect for Charter Rights of Accused at the Supreme Court in 2012-2013"; and V. MacDonnell, "The Jury Vetting Cases: New Insights on Jury Trials in Criminal Cases", Constitutional Cases 2012, supra, note 5.
} 
in three instances, ${ }^{14}$ and looked at one issue under mobility rights. ${ }^{15}$ The claim failed six times, succeeded twice, and was mixed in two cases; all told, then, the Charter's 2012 success rate in raw terms was 20 per cent. ${ }^{16}$

Rounding the picture out are six non-Charter decisions on rights. In that group, the claim succeeded three times on questions relating to Aboriginal sentencing, third party standing to intervene and discrimination under human rights laws; in other cases the rights-based claim failed on issues of elections law and expressive freedom, and was mixed on an open justice question. ${ }^{17}$ Three decisions released in early 2013 also deserve mention in this review, because the retirement of Deschamps J. in August of 2012 triggered a six-month deadline for decision-making to be completed in the appeals she heard. While the equality and expressive freedom claims in Quebec (Attorney General) v. A. and Saskatchewan (Human Rights Commission) v. Whatcott suffered losses, Manitoba Métis Federation v. Canada produced a more positive, though mixed, disposi-

14 L. (S.) v. Commission Scolaire des Chênes, [2012] S.C.J. No. 7, [2012] 1 S.C.R. 235 (S.C.C.) [hereinafter "L. (S.)"] (s. 2(a)); R. v. Khawaja, id. (s. 2(a), (b) and (d)); S. (N.), id. (s. 2(a)). Khawaja and $S$. (N.) engaged legal rights and the fundamental freedoms together. See R. Agarwal \& C. Di Carlo, "The Importance of Context: A Critical Analysis of the Supreme Court of Canada's Decision in R. v. S. (N.)", Constitutional Cases 2012, supra, note 5.

15 Sriskandarajah v. United States of America, [2012] S.C.J. No. 70, [2012] 3 S.C.R. 609 (S.C.C.) [hereinafter "Sriskandarajah"] (s. 7; mobility rights).

${ }_{16}$ The claim failed in L. (S.), Cole, Aucoin, Nedelcu, Khawaja and Sriskandarajah, succeeded in Tse and Bellusci, and was mixed in St-Onge Lamoureux (partial success) and S. (N.) (claim remitted for decision on the correct Charter standard).

17 R. v. Ipeelee, [2012] S.C.J. No. 13, [2012] 1 S.C.R. 433 (S.C.C.) [hereinafter "Ipeelee"] (Aboriginal sentencing); see J. Gevikoglu, "Ipeelee/Ladue and the Conundrum of Indigenous Identity in Sentencing", and M-E. Sylvestre, "The (Re)discovery of the Proportionality Principle in Ipeelee: Constitutionalization and the Emergence of Collective Responses"; Canada (Attorney General) v. Downtown Eastside Sex Workers United Against Violence Society, [2012] S.C.J. No. 45, [2012] 2 S.C.R. 524 (S.C.C.) [hereinafter "Downtown Eastside"] (public interest standing); see R. Sharpe, "Access to Charter Justice" (keynote presentation); Moore v. British Columbia (Education), [2012] S.C.J. No. 61, [2012] 3 S.C.R. 360 (S.C.C.) [hereinafter "Moore"] (discrimination); see R. Charney \& S. Kraicer, "Moore v. British Columbia: A Good IDEA?"; Opitz v. Wrzesnewskyj, [2012] S.C.J. No. 55, [2012] 3 S.C.R. 76 (S.C.C.) [hereinafter "Opitz"] (elections law); see Y. Dawood, "Democracy and Dissent: Judicial Review of the Political and Constitutional Aspects of the Electoral System" [hereinafter "Dawood"]; Doré v. Barreau du Quebec, [2012] S.C.J. No. 12, [2012] 1 S.C.R. 395 (S.C.C.) [hereinafter "Doré"] (administrative law; expressive freedom); see A. Cameron \& P. Daly, "Furthering Substantive Equality Through Administrative Law: Charter Values in Education"; and H. Kong, "Doré, Proportionality and the Virtues of Judicial Craft"; and B. (A.) v. Bragg Communications Inc., [2012] S.C.J. No. 46, [2012] 2 S.C.R. 567 (S.C.C.) [hereinafter "Bragg Communications"] (anonymity and publication ban), Constitutional Cases 2012, supra, note 5 (publishing all the articles cited in this footnote). Note also that the claim in Moore succeeded on the question of discrimination but not on the question of broad systemic remedies. 
tion under section 35 of the Constitution Act, 1982. ${ }^{18}$ Counting these cases raises the Charter output to 12 , but drops the success rate to about 16 per cent. Arithmetic that presents a blunt picture can be qualified, but only so far, and it is an unavoidable conclusion that the Charter fared poorly at the Court in 2012. ${ }^{19}$

An annual quantitative analysis of the Charter jurisprudence is one of the conference's many contributions over the years. According to the data from 2000 to the present, Charter claims succeeded in the first 10 years of the McLachlin Court at a rate of about 45 per cent, on average. ${ }^{20}$ There have been wobbles along the way and some years do not fit the profile, like 2008, when the success rate soared to 70 per cent, ${ }^{21}$ and 2005 and 2007, when it dipped to 20 per cent and 25 per cent, respectively. ${ }^{22}$ This has been the trajectory of Charter decision-making up to 2010 , with rates of success in other years, as follows: 30 per cent

18 Quebec (Attorney General) v. A., [2013] S.C.J. No. 5, 354 D.L.R. (4th) 191 (S.C.C.) [hereinafter "Quebec v. A."] (equality); see B. Ryder, "The Strange Double Life of Canadian Equality Rights" in Constitutional Cases 2012, supra, note 5; Whatcott, supra, note 10 (expressive freedom); see M. Freiman, "Hate Speech and the Reasonable Supreme Court of Canada" [hereinafter "Freiman"]; C. Zwibel, "Reconciling Rights: The Whatcott Case as Missed Opportunity" [hereinafter "Zwibel"] in Constitutional Cases 2012, supra, note 5; and Manitoba Métis Federation Inc. v. Canada (Attorney General), [2013] S.C.J. No. 14, 355 D.L.R. (4th) 577 (S.C.C.) [hereinafter "Manitoba Métis"] (s. 35 Aboriginal rights). Note that Quebec v. A. took 12 months to decide; Whatcott and Manitoba Métis each were 16 months between hearing and decision, and Deschamps J. was unable to participate in either as a result. Compare R. v. TELUS Communications Co., [2013] S.C.J. No. 16, 356 D.L.R. (4th) 195 (S.C.C.), which is not considered in the 2012 jurisprudence despite being a Charter success, because it is truly a 2013 decision, having been heard late in 2012 and decided in 2013.

19 As noted, the result was mixed in a couple of instances, supra, note 16, and how Whatcott, id., should be characterized, in win and loss terms, can be debated.

${ }^{20}$ P. Monahan \& J. Yap, "Constitutional Cases 2009: An Overview" (2010) 51 S.C.L.R. (2d) 3, at 4 [hereinafter "Constitutional Cases 2009"] (stating that, up to 2009, the McLachlin Court allowed " 63 of 139 Charter claims for an overall success rate of 45 per cent during the decade").

21 In discussing 2008, in which the Charter enjoyed the highest success rate since 1985, Monahan and Yap explain that when 2008's success is read against 2007, when Charter claimants only prevailed in three of 12 cases or 25 per cent of the time, the two-year success rate remained at 45 per cent, "consistent with the McLachlin average", and "yet another downward trend from 2007 was balanced out in 2008". P. Monahan \& J. Yap, "Constitutional Cases 2008: An Overview" (2009) 47 S.C.L.R. (2d) 3, at 4 [hereinafter "Constitutional Cases 2008"].

P. Monahan \& C. Kurtz, "The Supreme Court of Canada in 2005: The Year in Review" (2006) 34 S.C.L.R. (2d) 3, at 4 [hereinafter "Constitutional Cases 2005"] (noting the departure from recent experience under the McLachlin Court); P. Monahan \& J. Gotowiec, "Constitutional Cases 2007: An Overview" (2008) 42 S.C.L.R. (2d) 3, at 4 [hereinafter "Constitutional Cases 2007"] (noting that, at 58, the Court decided the lowest number of cases in 2007 since 1975, and further observing that the Court "was not particularly receptive" to the Charter and that the 25 per cent success rate indicated a decline from the average success rate of the recent past). 
$(2000) ;{ }^{23} 50$ per cent $(2001) ;{ }^{24} 63$ per cent $(2002) ;{ }^{25} 65$ per cent $(2003) ;{ }^{26}$ 41 per cent $(2004),{ }^{27} 70$ per cent $(2008) ;{ }^{28}$ and 40 per cent $(2009){ }^{29}$

Against those numbers, it is revealing that the success rate for the Charter has not risen above 20 per cent since 2010. In 2011 there were 19 constitutional decisions on an output of 75 decisions, and in 11 arising directly under the Charter, the claim succeeded no more than twice, at a rate of 18 per cent. ${ }^{30}$ The year before, in 2010, the Supreme Court decided 25 constitutional cases, and of the 17 that engaged the Charter there was a positive result in only three instances, or 18 per cent of the cases once more. ${ }^{31}$ From that perspective, the 2012 rate of 20 per cent is not anomalous, but rather conforms to the Court's pattern of Charter decision-making in the last three years.

The quantum of cases decided annually also provides a useful measure of the Charter's activity level at the Supreme Court. Another pattern that has been identified and discussed is the McLachlin Court's declining docket, both generally and on Charter claims as well. Monahan first noted a drop in 2001, from approximately 111 decisions annually during

23 P. Monahan, "Constitutional Cases 2000: An Overview" (2001) 14 S.C.L.R. (2d) 3 [hereinafter "Constitutional Cases 2000"].

24 P. Monahan, "Constitutional Cases 2001: An Overview" (2002) 16 S.C.L.R. (2d) 1, at 2 [hereinafter "Constitutional Cases 2001"] (noting that, at 50 per cent, the 2002 Charter jurisprudence equals the highest success rate for claims in the last decade).

25 P. Monahan \& N. Blum, "Constitutional Cases 2002: An Overview" (2003) 20 S.C.L.R. (2d) 3 [hereinafter "Constitutional Cases 2002"].

P. Monahan \& J. Cameron, "Constitutional Cases 2003: An Overview" (2004) 24 S.C.L.R. (2d) 1, at 2 [hereinafter "Constitutional Cases 2003"] (commenting that the McLachlin Court "continues to be extremely receptive to Charter claims", noting a marked increase in the success rate of claims, and noting an overall success rate of 53 per cent since the McLachlin Court's inception).

27 P. Monahan \& E. Van Dyk, "Constitutional Cases 2004: An Overview" (2005) 24 S.C.L.R. (2d) 1, at 2 [hereinafter "Constitutional Cases 2004"].

${ }_{28}$ Monahan \& Yap, Constitutional Cases 2008, supra, note 21, at 3 (stating also that this was the highest success rate since 1985).

29 Monahan \& Yap, Constitutional Cases 2009, supra, note 20. Note that numbers for 2006 are not available because the 25th anniversary program in 2007 did not provide an annual overview.

30 P. Monahan \& C. Sethi, "Constitutional Cases 2011: An Overview", in Constitutional Cases 2011, supra, note 3, at 5 (stating that "[a]lthough the sample size is small, this success rate is below the McLachlin Court's average of 41 per cent for Charter claims over the last decade (68 out of 167 such cases, including the 2011 cases")). Note also that although 16 cases are included in the inventory, 11 arose under the Charter and the other five which did not are mentioned and discussed nonetheless because they engaged Charter values.

31 P. Monahan \& C. Sethi, "Constitutional Cases 2010: An Overview" (2011) 54 S.C.L.R. (2d) 3, at 5 [hereinafter "Constitutional Cases 2010"] (noting that the success rate in 2010 was well below the McLachlin Court's average of 42 per cent — based on 66 of 156 cases since 2000). 
the 1990 s to an output of 72 that year. ${ }^{32}$ Since then, the Court's output dipped to 58 in 2006 and 70 in 2008, which at the time was the second lowest in a decade. It fell below 70 again in 2010, when the Court decided 69 cases. From a high of 91 in 2001 to a low of 58 in 2006, the numbers confirm Monahan and Yap's 2009 conclusion of "a general downward trend" in the McLachlin Court's annual output over a 10-year period. ${ }^{33}$ The Charter numbers have also varied, though less dramatically, from a low of 10 decisions in 2000, 2007 and 2012, to a high of 19 in 2001. In other years of low Charter output, the success rates for claims — at 30 per cent in 2000 and 70 per cent in 2007 - were higher than 2012's 20 per cent.

Numbers that provide useful information should not be treated as fetish, and nor should their significance be exaggerated. In considering the downward trend, it is worth remembering that the McLachlin Court's pre-2010 historic rate compares favourably with data from the 1990s, which show a swing, from a low Charter success rate of 21 per cent in 1993 to a high of 50 per cent in 1997, albeit on a higher volume of constitutional decision-making. ${ }^{34}$ As well, qualitative results and breakthroughs can offset or compensate for modest numbers; it is telling, in that regard, that the McLachlin Court has issued one or more landmark decisions in almost every year since 2000, including those with modest rates of success for Charter claims. ${ }^{35}$ Another element in assessing the Court's work is whether and in what cases it achieved consensus, and whether, why and with what

\footnotetext{
32 Monahan, Constitutional Cases 2001, supra, note 24, at 3.

33 Monahan \& Yap, Constitutional Cases 2009, supra, note 20, at 4 . That trend is now a pattern. In 2010 the Court decided 69 cases; in 2011 the number was 71; and in 2012, as indicated above, the number was 75 .

34 See Table 1 in Monahan, Constitutional Cases 2001, supra, note 24, at 5.

35 In 2005, for example, the Charter rate of success was relatively low, at 20 per cent, and "while in percentage terms the Court may have appeared unreceptive to Charter claims", by far "the most significant decisions of the year" and "potentially of the decade" was Chaoulli v. Quebec (Attorney General), [2005] S.C.J. No. 33, [2005] 1 S.C.R. 791 (S.C.C.) (adopting a novel interpretation of s. 7 by plurality opinion and finding that Quebec restrictions on access to private health insurance violated the Canadian Charter and Quebec Charter of human rights and freedoms, R.S.Q. c. C-12 [hereinafter "Quebec Charter"]); Monahan \& Kurtz, Constitutional Cases 2005, supra, note 22, at 5. Though the 2012 jurisprudence did not yield a landmark, 2011 and 2010 produced significant decisions, including Canada (Attorney General) v. PHS Community Services Society, [2011] S.C.J. No. 44, [2011] 3 S.C.R. 134 (S.C.C.) (s. 7 and a constitutional exemption); R. v. Conway, [2010] S.C.J. No. 22, [2010] 1 S.C.R. 765 (S.C.C.) (administrative tribunals and their Charter jurisdiction); Vancouver (City) v. Ward, [2010] S.C.J. No. 27, [2010] 2 S.C.R. 28 (S.C.C.) (remedies; Charter damages); Globe and Mail v. Canada (Attorney General), [2010] S.C.J. No. 41, [2010] 2 S.C.R. 592 (S.C.C.) (journalist-source privilege).
} 
incidence the judges have disagreed. ${ }^{36}$ Not surprisingly, the rate of dissent has also varied over the years. ${ }^{37}$

Much can be said, by way of qualitative analysis, about levels of agreement and disagreement in judicial decision-making, and this year's conference volume includes commentary on the nature and significance of dissent. ${ }^{38}$ In 2012, the Court was unanimous in Tse, Khawaja, Sriskandarajah and Bellusci, as well as in four of the six non-Charter rights decisions, but divided in six of the 10 Charter cases, two of the non-Charter rights decisions, and two of the three early 2013 decisions. ${ }^{39}$ As might be expected, dissenting and concurring opinions reveal healthy debate on the issues; examples in this review period include $S$. (N.), concerning a witness's right to wear a niqab and the accused's right of full answer and defence; Nedelcu, testing the scope of self-incrimination under section 13; Quebec v. A., seeking equality under section 15 for partners in common law unions that dissolve; and Métis Federation, asking for judicial declarations on honour of the Crown and breach of fiduciary duty.

Elsewhere, though differences of opinion were expected to emerge in two high stakes cases on fundamental freedom, both were decided by

36 For conference papers this year that assess the Court's work on questions of proportionality, see C. Bredt \& H. Pessione, "The Death of Oakes: Time for a Rights-Specific Approach"; J. McGill, "Section 15(2), Ameliorative Programs, and Proportionality Review"; and D. Schneiderman, "Judging in Secular Times" in Constitutional Cases 2012, supra, note 5.

37 On the numbers, compare 2001, where Monahan reported a rate of 82 per cent unanimity in the Court's decisions, "the highest in the past 15 years" with a 50 per cent Charter success rate that year, and 2007, where Monahan and Gotowiec found "[j] ust 63\% of judgments as being unanimous" and commented that this level of agreement was "the lowest since the mid-1990s and a departure from the McLachlin Court's overall average of 75\%". Monahan, Constitutional Cases 2001, supra, note 24, at 4; Monahan \& Gotowiec, Constitutional Cases 2007, supra, note 22, at 4. Note also that the per cent numbers on unanimity reference the year's decisions and not the Charter subset.

C. Mathen, "The Upside of Dissent in Equality Jurisprudence" in Constitutional Cases 2012, supra, note 5; Dawood, supra, note 17; D. Rankin \& M. Jamal, "Dissents and Concurrences: Seven Debates in Charter Jurisprudence" in Constitutional Cases 2012, supra, note 5.

The Court divided in these Charter cases: L. (S.), supra, note 14 (LeBel, Fish JJ., concurring); Cole, supra, note 13 (Abella J., dissenting); St-Onge, supra, note 13 (Rothstein, Cromwell JJ., dissenting); Nedelcu, supra, note 13 (LeBel, Fish, Cromwell JJ., dissenting); Aucoin, supra, note 13 (LeBel, Fish JJ., dissenting); and S. (N.), supra, note 13 (LeBel, Rothstein JJ., concurring, and Abella J., dissenting). In the non-Charter cases it was unanimous in Doré, supra, note 17 (Abella J.); Bragg Communications, supra, note 17 (Abella J.); Moore, supra, note 17 (Abella J.), and Downtown Eastside, supra, note 17 (Cromwell J.) but not in Ipeelee, supra, note 17 (Rothstein J., dissenting) and Opitz, supra, note 17 (McLachlin C.J.C., LeBel, Fish JJ., dissenting). As for early 2013, it was divided in Quebec v. A., supra, note 18 (Deschamps, Cromwell, Karatkatsanis, Abella JJ.), and Manitoba Métis, supra, note 18 (Rothstein, Moldaver JJ., dissenting) but unanimous in Whatcott, supra, note 10. 
unanimous opinion. If consensus reflects favourably on the Court and its leadership, solidarity also means that a conception of the Charter and its rights carries the endorsement of the institution. Though the assumption may be stronger or weaker for case-specific reasons, it is often thought that unanimous opinions speak with greater authority and bear more weight as precedent. With that in mind, the Court's solidarity in $R$. $v$. Khawaja ${ }^{40}$ and Saskatchewan (Human Rights Commission) v. Whatcott is puzzling, but indicative, as well, of the McLachlin Court's limited insight on the fundamental freedoms, and more generally of its current approach to rights protection. ${ }^{41}$

\section{CHARTER BELLWETHERS}

Two cases stand out as bellwethers: despite raising critical issues about the permissibility of heavy restrictions on section 2's fundamental freedoms, both dismissed the Charter claim by unanimous decision. R. v. Khawaja considered the motive clause in the Criminal Code's anti-terrorism provisions, which has been a lightning rod for concerns that individuals could be singled out for investigation and prosecution on the basis of assumptions about their willingness to support or engage in terrorist acts. Meanwhile, against the backdrop of close divisions in earlier decisions and extensive debate in the interim, Whatcott asked whether the McLachlin Court would protect expressive freedom, or subordinate it to the anti-discrimination objectives of human rights legislation.

R. v. Khawaja tested the constitutionality of the Criminal Code's threshold definition of terrorist activity and criminalization of "religious, political or ideological" motives. ${ }^{42}$ Khawaja was not the first time the Court considered Parliament's post 9/11 package of anti-terrorism laws. In 2004, a majority upheld section 83.28's investigative hearing mechanism, but did so against two dissenting opinions joined by three members of the Court. ${ }^{43}$ At the same time, the Court issued a second decision in

\footnotetext{
$40 \quad$ Supra, note 9.

41 Supra, note 10.

42 Supra, note 9. Section 83.01(1)(b)(i)(A) defines terrorist activity as an act or omission that is committed "in whole or in part for a political, religious or ideological purpose, objective or cause". Criminal Code, supra, note 8.

43 Re Application under s. 83.28 of the Criminal Code, [2004] S.C.J. No. 40, [2004] 2 S.C.R. 248 (S.C.C.) (LeBel, Fish JJ., dissenting on the constitutionality of the provision; LeBel, Fish,
} 
Vancouver Sun, which undermined the provision's feasibility by imposing a presumption of openness on all investigative hearings. ${ }^{44}$ This requirement made it substantially more difficult, if not practically impossible, for these hearings to be held; the Court was sharply divided, as a result, in deciding between the Charter and law enforcement objectives. ${ }^{45}$ Like the motive clause, the provisions for investigative hearings and preventive detention were hotly debated when anti-terrorism legislation was enacted, and again at the time of its five-year review. ${ }^{46}$ Though the McLachlin Court's decisions on investigative hearings reflected that broader debate in disagreements among the judges, its response to the motive clause was quite different. In 2012, the Court dismissed Khawaja's Charter challenge by unanimous decision. ${ }^{47}$

Alongside section 7 claims that also failed, Khawaja required the Court to consider definitional overreach in the Criminal Code's antiterrorism provisions, and its consequences for section 2's fundamental freedoms. ${ }^{48}$ The motive clause, which is a pivot in the definition of terrorist activity, spawned an amendment even before the legislation was enacted in $2001 .^{49}$ At the time of five-year review, the Senate Report recommended that it be repealed, and the Arar Inquiry commented extensively on the issue of profiling. ${ }^{50}$ The fear around this clause is that authorities can use its identifiers to target individuals who might be exercising protected constitutional rights. Its value in the war on terrorism

Binnie JJ., dissenting on the ground that the investigative hearing had been used for an inappropriate purpose in the Air India investigation).

44 Re Vancouver Sun, [2004] S.C.J. No. 41, [2004] 2 S.C.R. 332 (S.C.C.).

45 Bastarache J., with Deschamps J. concurring, wrote a strong dissent in this case.

46 See Bill 7, Combating Terrorism Act, S.C. 2013, c. 9 (reinstating investigative hearings and preventive detention provisions for another five-year period).

47 Khawaja was decided by a panel of seven, with Deschamps and Moldaver JJ. not participating in the appeal.

48 For comment on the Court's s. 7 discussion see H. Stewart, "R. v. Khawaja: At the Limits of Fundamental Justice" in Constitutional Cases 2012, supra, note 5; P. Sankoff, "Khawaja: Mixed Messages on the Meaning of Intention, Purpose and Desire" (2013) 97 C.R. (6th) 280.

See s. 83.01(1.1), which narrowed the scope of the clause by stating, "for greater certainty", that expression covered by the clause is not terrorist activity unless it also constitutes an act or omission that otherwise satisfies the criteria of s. 83.01(1)(b) (i.e., which lists a series of violent acts).

50 Special Senate Committee on the Anti-Terrorism Act, Fundamental Justice in Extraordinary Times, February 2007, Recommendation 3; see also, at 18-29 (acknowledging and discussing concerns about profiling and targeting after hearing from numerous witnesses on this issue). K. Roach, "Terrorism Offences and the Charter: A Comment on R. v. Khawaja" (2007) 11 Can. Crim. L.R. 271, at 289 (citing the Arar Report's comments on profiling). 
has been questioned and debated at length in the years since 2001..$^{51}$ Though the trial judge found the motive clause unconstitutional and severed it from the provision, the Ontario Court of Appeal reversed that decision. $^{52}$

Against that pedigree of controversy, the Supreme Court held in Khawaja that the clause does not violate the Charter. Section 83.01's references to political, religious and ideological objectives automatically engaged section 2(a) and (b), but also implicated section 2(d)'s guarantee of associational freedom. Despite the sweep across section 2's fundamental freedoms, the Chief Justice's majority opinion began by reading religious and associational freedom out of the appeal. Doing so rendered those freedoms invisible and minimized the scale of interference with fundamental freedoms. In effect, section 2's other guarantees were subsidiary to expressive freedom and became redundant, or irrelevant, once the section 2(b) claim failed. ${ }^{53}$

Read on its own, the motive clause strikes at the core of expressive freedom by criminalizing political, religious and ideological purposes, objectives and causes. For that reason, the clause per se and on its face violates section 2(b). Under longstanding doctrine, purposeful violations of expressive freedom are prima facie in breach of the guarantee, and shift without more to section 1 for justification. ${ }^{54}$ That conclusion did not follow in Khawaja because of the violence exception, which excludes acts and threats of violence from section 2(b). ${ }^{55}$ Accordingly, the Chief Justice relied on that exception to skirt the question of purposeful violation and decide, without hesitation, that the conduct caught by the terrorism provisions falls within the exception. ${ }^{56}$ Certain language in other parts of the definition raised lingering concerns that non-violent or constitutionally

51 Some countries have such clauses and others do not (i.e., the U.S., UN and European nations). In Suresh v. Canada, [2002] S.C.J. No. 3, [2002] 1 S.C.R. 3 (S.C.C.) the Supreme Court adopted its own definition of terrorism which did not include any element of this kind.

${ }_{52}$ R. v. Khawaja, [2010] O.J. No. 5471, 103 O.R. (3d) 321 (Ont. C.A.) [hereinafter “Khawaja (C.A.)"]; [2006] O.J. No. 4245, 214 C.C.C. (3d) 399 (Ont. S.C.J.).

53 Khawaja, supra, note 9, at para. 66 (concluding that there is no s. 2(a) or s. 2(d) claim if s. 2(b) is not infringed).

54 Irwin Toy v. Quebec (Attorney General), [1989] S.C.J. No. 36, [1989] 1 S.C.R. 927 (S.C.C.) [hereinafter "Irwin Toy"] (establishing the two-step purpose and effects test for breach under s. 2(b)).

55 Greater Vancouver Transportation Authority v. Canadian Federation of Students, [2009] S.C.J. No. 31, [2009] 2 S.C.R. 295, at para. 28 (S.C.C.) (commenting on the violence exception).

56 Khawaja, supra, note 9, at para. 71 (stating that "[m]ost of the conduct caught by the terrorism provisions ... concern acts of violence or threats of violence" and the "conduct falls outside the protection of s. 2(b))". 
protected activity might be at risk. In response to that concern, the Chief Justice kept the Charter issue hypothetically alive for the clause that targets activities causing serious interference or disruption. ${ }^{57}$

The motive clause criminalizes purposes, objectives and causes that are abstract in the definition, but inescapably content-based in their application. The clause does not explicitly address acts or threats of violence, but rather throws a dragnet over "motives" which, apart from any act of violence, are constitutionally protected. In such circumstances, it is troubling that the Chief Justice's analysis of purposeful violation was perfunctory, and did not ask whether the motive clause itself is caught by the violence exception, and excluded from section 2(b) on that basis. Nor did the Chief Justice mention, much less analyze, whether section 83.01(1.1) resolved concerns that the clause draws no distinction between protected and unprotected, or violent and non-violent purposes, objectives, and causes. ${ }^{58}$ The Charter might permit the state to lever the definition of terrorist activity by striking at constitutionally protected activity, but surely only after it meets its burden under section 1 to demonstrate that the motive clause is a justifiable and proportionate element of the Code's definition of terrorist activity.

Ignoring the motive clause's purposeful violation of section 2(b) activated the guarantee's alternative route to section 1 , which considers whether a provision impermissibly affects section 2(b) ${ }^{59}$ There, the Chief Justice followed the lead of the Ontario Court of Appeal and essentially adopted its reasons for rejecting a breach based on chilling effects, though with less analysis in doing so. Reasons that are also perfunctory on this issue indicate that the Court did not give the argument from chill much credence. The Chief Justice disagreed with the Ontario Court of Appeal that chill must always be proved by evidence, but then went on to

$57 \quad I d$., at para. 74 (stating that the activities caught by s. 83.01(1)(b)(ii)(E) of the Criminal Code, supra, note 8 - the interference and disruption clause - do not fall within the protected zone of free expression, without ruling out the possibility that the provision could in some future case capture protected activity).

Although s. 83.01(1.1), id., appears to narrow the scope of the motive clause, its constitutionality remains unclear, both because this provision fails to disentangle the proscribed "acts or omission" - which are forms of conduct - from purely expressive activities, and also because it assumes the constitutionality of the acts and omissions described in the paragraph (i.e., that the criteria, as set out, cannot catch non-violent expressive activities). Khawaja mentioned it only in discussion of the motive clause's chilling effects and not on the question of purposeful violation; Khawaja, supra, note 9, at para. 82 (discounting a chilling effect because "[a]nyone who reads the entire provision" will take notice of s. 83.01(1.1) and its narrowing scope)

$59 \quad$ Irwin Toy, supra, note 54. 
apply a double standard and state that, in this case, evidence of a connection between the clause and a chill was nonetheless required. ${ }^{60}$

From there, she adopted the three reasons the appellate court gave for dismissing the chilling effects claim. First, the Chief Justice agreed that any negative impact on the fundamental freedoms is related to $9 / 11$ and its aftermath, and not to the motive clause. ${ }^{61}$ In effect, this sent a message that the state is entitled to capitalize on a climate of suspicion, and escalate or aggravate an existing chill by criminalizing activity that has already been marginalized. Second, she held that the legislation is not responsible if groups or individuals self-censor, or are deterred from exercising their fundamental freedoms. In her view, the chill in those circumstances can only stem from their flawed understanding of the legislation, and unfounded fear that it might apply to legitimate, non-violent activity. ${ }^{62} \mathrm{In}$ other words, any such chilling is self-generated or self-inflicted, and not linked to the provision's express targeting of motive. Finally, the Chief Justice emphasized that profiling is not a concern either, because any targeting by authorities can only occur through police misconduct. ${ }^{63}$ Under that view, the motive clause is not accountable for problems that arise, because it neither authorizes nor invites authorities to exercise powers that are illegal or unconstitutional. ${ }^{64}$

It is difficult to imagine how Khawaja could be less sympathetic to the Charter's fundamental freedoms and to activities which - being political, religious and ideological in nature - sit at the core of the guarantee. Though the definition of terrorist activity was controversial from the outset, little in the Court's opinion acknowledges, much less

60 Khawaja, supra, note 9, at paras. 79-80 (acknowledging that the chilling effect can "be inferred from known facts and experience", then agreeing with the Ontario C.A. that an inference of chill from the motive clause cannot be drawn without evidence).

${ }_{61} I d$., at para. 81. The Ontario Court of Appeal put the point in blunt terms, stating that "[i]t is hardly surprising that, in the public mind, terrorism is associated with the religious and political views of radical Islamists" and "[n]or is it surprising that some extend that association to all who fit within a very broad racial and cultural stereotype of a radical Islamist"; Khawaja (C.A), supra, note 52 , at para. 126.

$62 \quad I d$., at para. 82 (stating that the clause would only have a chilling effect on those who have "cursory or incomplete knowledge of s. 83.01", and that only individuals who go well beyond legitimate expression need fear liability under these provisions). See also Khawaja (C.A.), id., at para. 128 (imposing a burden on individuals — in avoiding self-censoring — to be aware of s. 83.01(1.1) and its narrowing of the motive clause).

63 Id., at para. 83 .

64 Id. (stating, without reservation, that the clause raises "no concerns with respect to improper stereotyping"). See also Khawaja (C.A.), supra, note 52, at paras. 132-135 (concluding that if there is any chill its source is the actions of terrorists, and not the legislation). 
confronts or addresses, those concerns. The Court made little or no effort to explain the role of the motive clause in the framework of complex anti-terrorism provisions, or to consider the relationship between the motive clause and section 83.01(1.1). The majority opinion blanked the question of purposeful violation out, and did not offer an interpretation or warning to narrow the motive clause's reach (i.e., stressing, for example, that it only applies in limited circumstances where the violence criteria are satisfied). The McLachlin Court is known for its diligence in reading statutory provisions carefully, noting whatever reservations or qualifications are necessary to ensure compliance with the Charter. Its failure to do so in Khawaja likely shows that the Court did not consider section 2's fundamental freedoms to be truly at risk under the Code's definition of terrorist activity.

After negating the question of purposeful violation with a reflexive turn to the violence exception, the Court dismissed the impact on constitutionally protected activities by shifting responsibility for chilling effects from lawmakers to $9 / 11$ itself, to groups or individuals who selfcensor because they misunderstand the clause, and to those in authority who might engage in profiling, because they also misunderstand and misconstrue powers that are conferred by the clause. It is disheartening that no member of the panel saw a breach of the Charter's fundamental freedoms, or a need, at the very least, to put the government to the test of justification under section 1 .

A few months after Khawaja, the Court dismissed the claim in Whatcott, once again by unanimous vote. To the extent the Court may have been particularly compelled to defer to Parliament's judgment in enacting anti-terrorism measures, an appeal to deference was less convincing in Whatcott. ${ }^{65}$

In the context of flyers attacking gays and their visibility in public schools, Whatcott asked whether anti-discrimination laws can be used to regulate offensive expression. ${ }^{66}$ Though the Court's decision reads on its

65 On other terrorism-related issues compare Suresh v. Canada, supra, note 51 (deportation proceedings); Charkaoui v. Canada (Citizenship and Immigration), [2008] S.C.J. No. 39, [2008] 2 S.C.R. 326 (S.C.C.) [hereinafter "Charkaoui"] (security certificate, s. 7 fairness); Canada (Justice) v. Khadr, [2008] S.C.J. No. 28, [2008] 2 S.C.R. 125 (S.C.C.) (s. 7 disclosure); and Canada (Prime Minister) v. Khadr, [2010] S.C.J. No. 3, [2010] 1 S.C.R. 44 (S.C.C.) (remedy).

66 Supra, note 10. Section 14(1)(b) prohibits the publication or display of any representation "that exposes or tends to expose to hatred, ridicules, belittles or otherwise affronts the dignity of any person or class of persons on the basis of a prohibited ground": Saskatchewan Human Rights Code, S.S. 1979 , c. S-24.1. 
face as a draw, section 2(b) only prevailed on the obvious points of overbreadth and otherwise lost on the question of principle. Whatcott upheld section 14(1)(b) of Saskatchewan's human rights legislation, but read it down and read out certain words that unjustifiably infringe expressive freedom. ${ }^{67}$ Compromise on the question of law was followed by a second compromise, which found that while two of the flyers violated section 14, two others were protected by expressive freedom.

In this way, Whatcott presents on the surface as a balanced decision, one that weighed equality values and expressive freedom carefully before reaching a well-calibrated conclusion: that while expression is subject to human rights legislation, the freedom to state offensive and hurtful views is protected from overreaching views of equality's demands. Despite or in light of that balance, Whatcott must be seen as a signal defeat for section 2(b). The Court's correction of section 14 was modest, as the provision had already been read down judicially to comply with the definition of hate speech under the Court's earlier jurisprudence. Moreover, by 2012, there were no vestiges of the close margins and deep divisions which defined the Court's hate speech trilogy from the 1990s. In striking contrast, the Whatcott panel unanimously adopted Rothstein J.'s majority opinion. ${ }^{68}$

Though scarcely evident in that opinion, the backdrop is critical, for it shows what was at stake. Whether hate speech should be protected by the Charter and left to counter speech and the counsels of time, or regulated to avoid the risk that it might be believed and acted on, has posed one of modern expressive freedom's most difficult issues. As divisive today as it was 20-some years ago, debate on this issue has hardly abated. To the contrary, though with ebb and flow, the status of hate speech regulation has raged on, even as Whatcott reached the Court. Not only have there been high profile decisions and well-publicized reports in recent years, Parliament has repealed section 13, which was the Canadian Human Rights Act's ${ }^{69}$ hate speech provision. ${ }^{70}$

$67 I d$., at para. 92 (finding that s. 14's prohibition on expression that "ridicules, belittles, or affronts the dignity" of those protected from discrimination fails the rational connection test) and para. 206 (severing those words from the provision); see also paras. 41-42 (reading down the doctrinal definition of hate speech); and paras. 55-60 (confirming a "modified" definition of hatred).

68 Whatcott was decided by a panel of six, which comprised McLachlin C.J.C., with LeBel, Fish, Abella, Rothstein and Cromwell JJ. Justice Deschamps sat on the panel but did not participate in the decision.

69 R.S.C. 1985 , c. H-6.

70 Though the references could be countless in number, see especially Richard Moon, Report to the Canadian Human Rights Commission Concerning Section 13 of the Canadian Human 
When it addressed the Charter status of hate speech for the first time, the Court upheld Criminal Code and human rights provisions as reasonable limits on section 2(b), by margins of 4-3 in each instance. ${ }^{71}$ Soon after Keegstra and Taylor in 1990, the Court went the other way, and protected expressive freedom in $R$. v. Zundel - in a different statutory context, though on the related issue of holocaust denial - and again, by a 4-3 margin. ${ }^{72}$ The Supreme Court's decisions in Keegstra and Taylor were of transcending importance because they marked a turning point in the section 2(b) jurisprudence. ${ }^{73}$ Taken together, this trilogy of landmarks speaks to the raw conflicts these issues exposed, and how the panels wrestled with them in deciding Zundel differently than Keegstra and Taylor; the result was closely reasoned majority and dissenting opinions in all three. ${ }^{74}$ Even as the panel changed in R. v. Zundel, drawing other members of the Court into the debate, the balance of equilibrium - going first one way and then the other - could not have been closer. ${ }^{75}$

Whatcott provided the opportunity for the 2012 Court to revisit the status of hate speech from the vantage of fresh insight, developments, and perspective. Disappointingly, its response shows how much ground section 2(b) has lost in the interim. Justice Rothstein neither recognized

Rights Act and the Regulation of Hate Speech on the Internet (Ottawa: Canadian Human Rights Commission, 2008) [hereinafter "Moon Report"]; and Bill C-304, An Act to amend the Canadian Human Rights Act (Protecting Freedom), 1st Sess, 41st Parl., 2011 (Royal Assent on June 26, 2013, repealing s. 13 as of June 26, 2014). See also Zwibel, supra, note 18 (reviewing the key developments).

R. v. Keegstra, [1990] S.C.J. No. 131, [1990] 3 S.C.R. 697 (S.C.C.) [hereinafter "Keegstra"]; Canada (Human Rights Commission) v. Taylor, [1990] S.C.J. No. 129, [1990] 3 S.C.R. 892 (S.C.C.) [hereinafter "Taylor"].

${ }_{72}$ R. v. Zundel, [1992] S.C.J. No. 70, [1992] 2 S.C.R. 731 (S.C.C.) [hereinafter “Zundel”] (invalidating the false news provision of the Criminal Code).

73 Not only did the Court decide against expressive freedom in each, in doing so it developed a s. 1 methodology that made it easier to uphold limits on offensive expression and was applied in other cases to justify restrictions on a range of so-called "low value" expression expression that strayed from the "core" of s. 2(b)'s guarantee.

74 Chief Justice Dickson wrote majority opinions in Keegstra and Taylor, and McLachlin J. wrote dissents. In Zundel, McLachlin J. was author of the majority opinion and Cory and Iacobucci JJ. the dissent.

75 The Dickson majority in Keegstra and Taylor comprised the Chief Justice, together with Wilson, L'Heureux Dubé and Gonthier JJ.; the McLachlin minority included Justices Sopinka and La Forest. The panel in Zundel was differently constituted with McLachlin J. together with La Forest, L'Heureux Dubé and Sopinka JJ. in the majority, and Cory and Iacobucci JJ., joined by Gonthier J., in the minority. While Lamer J. did not participate in any of these cases, L'Heureux Dubé J. changed her vote from Keegstra and Taylor to Zundel. In 2012, McLachlin J. - now McLachlin C.J.C. - was the only member of the Court from these panels to serve again in Whatcott. 
nor discussed the opinions in the trilogy that defended expressive freedom, though then McLachlin J. played a leading role in all three. Against the debates that define the Keegstra-Taylor-Zundel trio, Whatcott's failure to canvass any alternative view is striking, and the majority opinion also chose not to review or discuss significant developments in the interim. ${ }^{76}$ In the circumstances, the silence is remarkable: Rothstein J.'s opinion did not provoke a whisper of dissent, or concurring remarks of any kind from other members of the panel.

By seemingly staking the middle ground, Rothstein J. made antidiscrimination law the victor in Whatcott. For present purposes, limited comments only will be made. ${ }^{77} \mathrm{~A}$ first considers whether, and under what view of the Charter, that middle ground was open, and a second comments on the decision's unanimity. A brief analysis shows that the existing methodology compromised section 2(b), and that Whatcott not only endorsed that methodology but took it a step further, thereby weakening expressive freedom yet more in the process. By agreeing, other members of the panel acquiesced in a view of section 2(b) that more deeply embedded its low status in the jurisprudence.

Justice Rothstein's characterization of the regulation and concept of harm are the keys to his section 2(b) methodology. To begin, he made the essential claim that hate speech regulations do not target ideas. Without invoking the vocabulary of content neutrality, he maintained that the violation of expressive freedom is not content-based, and cannot be considered a form of censorship. Despite agreeing that "[a] blanket prohibition on the communication of repugnant ideas would offend the core of freedom of expression", he declared that "[h]ate speech legislation is not aimed at discouraging repugnant or offensive ideas" ${ }^{78}$ The logic is that limits on ideas would offend section 2(b)'s core, but restrictions on hate speech are different, because they only attack the "mode of expression" and "effect" hate speech may have. ${ }^{79}$ To repeat, Rothstein J. was adamant that Saskatchewan's human rights provision regulates the mode and effect of the message, and not its content. Whatcott's pretense, then,

76 He cites the Moon Report, supra, note 70 once; Whatcott, supra, note 10, at para. 105.

77 For more detailed comments on Whatcott, see Freiman and Zwibel, supra, note 18.

78 Whatcott, supra, note 10, at paras. 50 and 51 (emphasis added).

$79 I d$., at para 51 (noting, with emphasis, the conjectural nature of the harm). See also para 58 (stating, once more, that the repugnancy of the ideas is not sufficient to justify restrictions and declaring that the prohibition of hate speech "is not designed to censor ideas or to compel anyone to think "correctly",). 
is that the content of hate speech is protected, though the mode of expressing it - hatefully - is not.

Yet Justice Rothstein's section 1 discussion confirms that his concept of hate speech is content based. There, he relied on the Keegstra-Taylor methodology, beginning with the proposition that "not all expression will be treated equally", and concluding that "[h]ate speech is at some distance from the spirit of s. 2(b) because it does little to promote, and can in fact impede, the values underlying freedom of expression". ${ }^{80}$ The methodology from the early 1990s invoked the "core" and "spirit" of section 2(b) not, as might be expected, to enhance expressive freedom's protection, but instead to permit limits whenever the content of a message could be described as having low value. Though Rothstein J. did not explicitly characterize the content at issue in Whatcott as low value, describing hate speech laws as neutral - in being aimed at modes and effects rather than messages - represents a serious retreat from content neutrality. ${ }^{81}$ This is how he circumvented the organizing principle that is so entrenched in the section 2(b) jurisprudence. It is true enough that the Court's commitment to content neutrality is little more than a formality, having been vanquished by section 1's content-based, core values approach; still, the principle was a fundamental tenet of section 2(b) prior to Whatcott. ${ }^{82}$

The assertion that Saskatchewan's human rights provision only targets hate speech's effects is directly related to Rothstein J.'s concept of harm. His distinction between offensive messages is based on a curious and unsupported assumption that hate speech has insidious effects, but merely repugnant and offensive messages do not. In other words, Whatcott proposed that hate speech can be defined and regulated on an exceptional basis because of its distinctive effects. ${ }^{83}$

\footnotetext{
${ }^{80} \quad I d$., at paras. 112 and 114 (emphasis added).

81 Irwin Toy, supra, note 54 (establishing content neutrality and the equal status of all ideas for purposes of determining the question of a s. 2(b) breach).

${ }_{82}$ See J. Cameron, "A Reflection on Section 2(b)'s Quixotic Journey: 1982-2012", in Constitutional Cases 2011, supra, note 3, at 163 (explaining the contradictory and incoherent nature of the Court's commitment to content neutrality under s. 2(b) and application of an explicitly content-based, core values methodology under s. 1).

83 According to Rothstein J., the distinction is between "mere disdain or dislike", "merely discrediting, humiliating or offending the victims" and repugnant and offensive ideas, on the one hand, and "[r]epresentations that expose a target group to detestation [and] tend to inspire enmity and extreme ill-will against them" or "incite the level of abhorrence, delegitimization and rejection that risks causing discrimination or other harmful effects". Whatcott, supra, note 10, at paras. 41, 57 and 58 .
} 
Though one is dominant, Rothstein J.'s concept of harm has two branches. Primarily, his view of harm is preventive and finds voice in repeated references to the harm hate speech could or can cause, if and when its messages are acted on and take the form of discriminatory conduct. $^{84}$ In other words, he does not state that hate speech is per se harmful, but instead finds that it may become an instrument of harm, if and when discriminatory acts are committed by a third party. Harm, in this view, is speculative, prospective, and essentially contingent in nature. The problem is that grounding limits in a risk of harm that is unknown - a form of harm in the making - places section 2(b) in jeopardy any time it is perceived that a message could lead to an act of harm in the future. Notably, the act that might occur is not committed by the speaker, but by others who engage in discriminatory behaviour. In this way, Rothstein J.'s concept of harm assumes that an actor who commits a subsequent discriminatory act was inspired by the speaker and, therefore, that the speaker can be held accountable preventively through the office of section 14.

He otherwise cited the social harm arising from hate speech, referring generally to "social disharmony" and "the need to protect the societal standing of vulnerable groups" ${ }^{85} \mathrm{He}$ spoke of its impact on target groups, claiming that it poses "a serious barrier to their full participation in our democracy", cuts off any reply by the group under attack, and forces the group to "argue for their basic humanity or social standing". ${ }^{86}$ Despite these mentions, Rothstein J. remained true to his primary concept of harm as the prospect or likelihood that third parties might act on hate speech. As he explained, the "concern is that some members of society will demonstrate their rejection of the vulnerable group through conduct". ${ }^{87}$

${ }^{84}$ See $i d$., among others, at paras. 2 (referring to expression which represents a "potential cause of the discriminatory practices the human rights legislation seeks to eliminate"); 48 (referring to prohibitions that aim to eliminate expression that has "the potential to incite or inspire discriminatory treatment" and is "likely to expose a protected group to hatred and potentially lead to the activity the legislature seeks to eliminate"); 52 (referring, again, to expression with the "potential" to lead to discrimination); 74 (stating that hate speech "lays the groundwork for later, broad attacks on vulnerable groups"); 82 and 92 (discussing the likely effects of hate speech) and 111 (referring, again, to expression which, "by inspiring hatred, has the potential to cause the type of harm the legislature is trying to prevent") (emphasis added in all instances).

$85 I d$., at paras. 74 and 82.

$86 \quad I d$. , at para. 75.

87 Id., at para. 74 (noting, by emphasis added, the change in verb tense). 
This definition of harm made it impossible for the Court to require proof, as none is available to support a hypothetical view of harm. The Court did not refer to evidence that hate speech leads to discriminatory acts or conduct by third parties, and the societal harm Rothstein J. spoke of was little more than a claim or argument, not supported by evidence. His methodology of reasonable limits relied instead on common sense, and he considered it sufficient simply to declare that "the discriminatory effects of hate speech are part of the everyday knowledge and experience of Canadians". ${ }^{88}$ He also invoked the Court's default under section 1, of deferring to the legislature when enforcing the Charter is undesirable. ${ }^{89}$

In concluding that hate speech is not protected by the Charter, Rothstein J. reverted to the Keegstra-Taylor methodology, which paired judicial assessment of expressive merit with an attenuated concept of harm. This combination became the means, in the 1990s and beyond, by which the Court upheld virtually all limits on expressive activity, including political as well as offensive expression..$^{90}$ Rather than rethink it in light of intervening debates about hate speech and expressive freedom more generally, Rothstein $J$. not only reverted to that methodology, but further diminished section 2(b) by denying that hate speech laws target content. It is telling of expressive freedom's low status at the Court that no member of the panel challenged this analysis, and especially unfortunate that the Court rejected an evidence-based concept of harm. In doing so, the McLachlin Court missed an opportunity to remind the federal government - and others - that limits on Charter rights and freedoms are supposed to be evidence-based.

Nor did Whatcott's middle-ground disposition salve the consequences for expressive freedom. The Court's insistence that the provision does not target ideas and that subjectivity has been eliminated is belied by the outcome, which showed how little agreement there was on the transgressive nature of the Whatcott flyers. The human rights tribunal and reviewing judge found that all four flyers violated the human rights

88 Id., at para. 135. See also para. 132 (stating that "a precise causal link for certain societal harms ought not to be required" and that a court is "entitled to use common sense and experience in recognizing that certain activities, hate speech among them, inflict harm").

${ }_{89} I d$., at para. 78 (stating that the legislature's approach must be accorded considerable deference; emphasis added).

${ }_{90}$ See, e.g., Harper v. Canada (Attorney General), [2004] S.C.J. No. 28, [2004] 1 S.C.R. 827 (S.C.C.) and R. v. Bryan, [2007] S.C.J. No. 12, [2007] 1 S.C.R. 527 (S.C.C.) (upholding restrictions on political expression which sits at the core of s. 2(b), without proof or evidence of its harmful effects). 
provision; the three-judge panel of the appellate court disagreed and found that none could be regulated; and the Supreme Court found, finally, that while two of the flyers did, two others did not. ${ }^{91}$ These proceedings demonstrate, yet again, that hate speech intractably and predictably defies objective measurement.

Khawaja and Whatcott share elements in common. Both came to the Court amid threshold debates about limits on the Charter's fundamental freedoms. ${ }^{92}$ The claim from freedom failed entirely in Khawaja, and then lost again at the level of principle in Whatcott. After concluding that the motive clause does not violate section 2(b), the Court claimed that hate speech regulations do not target the content of messages. Further indication of the Court's resistance to the fundamental freedoms in these cases is found in its opportunistic treatment of evidence requirements. Khawaja rejected the section 2(b) claim because the appellant failed to lead evidence to show that the motive clause has had a chilling effect, despite such evidence not being required in other cases. A few months later, Whatcott all but relieved the government of its evidentiary burden to demonstrate that hate speech is harmful. What was readily assumed there, as a matter of "everyday knowledge and experience of Canadians", was put to the proof under a different standard in the case of the motive clause. On this, the disconnect between the two is telling, because it shows how inconsistent approaches to the evidence worked consistently against expressive freedom. Though the outcome and methodology are profoundly disappointing, more discouraging yet is the lack of debate between members of the Court, at the level of transparency in judicial reasons. ${ }^{93}$

As Nedelcu, Opitz, S. (N.) and Quebec v. A. attest, the Court's disagreements in this review period offer a wealth of interpretive material. At the same time, its solidarity in Khawaja and Whatcott should not be overlooked, as consensus in closely watched cases sends an institutional message and projects a conception of rights that commands the

91 Whatcott, supra, note 10, at paras. 13-18 (summarizing the proceedings in courts and tribunals below).

92 Note that the hate speech in Whatcott was rooted in religious conviction; see Whatcott, $i d$., at paras. 152-163 (rehearsing the s. 2(a) analysis and coming to the same conclusion).

93 Most notable is the Chief Justice's ongoing retreat from the leadership and courage she displayed in protecting the Charter when she joined the Court. In addition to Keegstra and Taylor (dissenting opinions) and Zundel (majority opinion), McLachlin J. showed early leadership on s. 2(b) issues in the search warrant cases; see Canadian Broadcasting Corp. v. Lessard, [1991] S.C.J. No. 87, [1991] 3 S.C.R. 421 (S.C.C.); and Canadian Broadcasting Corp. v. New Brunswick (Attorney General), [1991] S.C.J. No. 88, [1991] 3 S.C.R. 459 (S.C.C.) (sole dissenting opinion). 
institution's endorsement. As for explanations, the Court's unanimity can be traced to one or more of: the issues at stake, the record, the written and oral advocacy, the technicalities of the appeal, the size and composition of the panel, internal discussion and the leadership of the opinions' authors. In qualitative terms, solidarity is facially neutral but, among other things, can reveal a diminished or enhanced conception of rights, a lack or presence of intellectual rigour and courage, and an institutional preference for a more diffident or more proactive conception of review.

If the Charter is in stall, there may be little reason to fear that it will not rebound. For the time being, with fewer cases being decided there may be fewer losses and fewer negative Charter precedents created (at least if the success rates in the last three years are an indication). This year's low success rate may be just as fortuitous as similar rates in 2010 and 2011, and the lack of a Charter landmark in 2012 may also be thought fortuitous. Likewise, unanimity in Khawaja and Whatcott might not seem so striking in light of debate in other cases.

Still, an unease remains which is based in an apprehension - despite the all's well explanations that can be advanced - that the Charter has been slipping. As shadowy and unformed as it is, this uneasiness has stirred the reflection that ends this review.

\section{THE CHARTER AND THE MidDlE GROUND}

In his exit interview in 2011, Binnie J. remarked that the McLachlin Court is more of a consolidator than a "cutting-edge innovator", then hastened to add, "[w]hich is not to say I see the court as timid". ${ }^{44} \mathrm{He}$ allowed that the Court is forceful when the occasion arises, but warned that "the legal landscape has changed and the court has evolved with the landscape". 95 In broad terms, his comments are consistent with a 2010 interview of McLachlin C.J.C., which took place on her 10th anniversary as Chief Justice. She reflected generally that the Supreme Court "did a huge amount of very good work laying down the basis" in the Charter's early years, and added that "[w]e are just building on that" ${ }^{96}$ She also intimated that with "most of the significant Charter of rights battles [having] been fought", the Court's mission under her leadership is "to

\footnotetext{
94 K. Makin, “Justice Ian Binnie’s Exit Interview”, September 23, 2011, The Globe and Mail. $95 \quad$ Id

96 K. Makin, "Ten Years as a Top Judge - And She Still Loses Sleep Over her Decisions", January 7, 2010, The Globe and Mail, A1.
} 
deal mainly with subtle interpretations". ${ }^{97}$ The Chief Justice confirmed these views in a very recent interview, which quotes her as remarking that "[t]here are fewer issues now" that "the heady days of the $80 \mathrm{~s}$ and early 90s" are over. ${ }^{98}$ She also expressed the view that most of the "big" Charter issues have been settled and the Court is now in a period of "fine tuning". 99

There can be no doubt that subtle interpretation and fine tuning are enormously important. Without discounting that work, characterizing what is at stake in Charter decision-making is a matter of perception and choice. From one point of view, the violence exception was dispositive in Khawaja and the chilling effect was not established; from another, though, the Charter challenge was critical because the motive clause strikes at section 2's core commitments. Similarly, Whatcott is more straightforward if the everyday experience and knowledge of Canadians can be deployed to override fundamental freedoms; seen otherwise, the status of hate speech in 2012 called for a deep look at the nature of freedom, what harm is in the context of discrimination, and the demands of risk management in a democracy.

How the 2012 jurisprudence and the Charter's prospects should be assessed also rest on perceptions and choices between alternative or overlapping explanations. The current dynamics may be fortuitous and untroubling, or not, depending on point of view. At the least, this review has confirmed a consistent downward trend on docket volume and success rates at the Supreme Court; it has shown that 2012 was a year of substantive mediocrity for the Charter; and it has aired its concerns about key decisions being decided by unanimous opinion. ${ }^{100}$ That said, the longer view is of more interest than the outcome in particular cases. The Chief Justice is respected as a leader who values consensus, but whether consensus is desirable more generally is not the issue here, and nor are the 2012 particulars as to docket, panel composition and Charter output.

Rather, the point for final reflection is that there are enough indicators, in 2012 and in recent history, to hint that a deeper turn in the Charter's evolution may be taking place. It is more like a gradual arc than a sharp turn, and does not emerge on a surface review of case-to-case and

\footnotetext{
$97 \quad$ Id.

$98 \quad$ J. Tibbetts, "Building Consensus", July 23, 2013, Canadian Lawyer, at 26.

$99 \quad$ Id.

100 Quebec v. A., supra, note 18, is another key decision which, as mentioned, exposed strong differences of opinion among the nine members of the Court.
} 
year-by-year assessment. What is at stake is a retreat or turn away from the Charter we once imagined and experienced, as a nimble document and an instrument of progress. Lately and increasingly, it seems instead that the Charter is stuck in the middle, implacable and passive for the most part, except when compelled on rare occasions to act on its promises. This shift is subtle, not only because the middle ground was available from the start, but also because rights protection under the Charter remains a force. Still, it is as though the Charter's first principles are being reversed, in at least some instances: though the Court once took pride in announcing that rights are the rule and limits the exception, the language and methodology of limits are more the norm now, and rights protection more the exception. To clarify, this is less a description of the jurisprudence or of Charter outcomes in this or recent years than an observation about how vocabulary and perception have shifted the momentum and emphasis in Charter interpretation.

In the post-1982 boom, the Supreme Court stepped up, addressing seemingly obvious and egregious Charter violations - often boldly and setting standards for Charter compliance in a number of landmark decisions. Yet the Chief Justice and others take the view today that the transformational energy of those early years has been depleted, and there is not so much left for the courts to do. Being satisfied that Canada's primary shortcomings on rights compliance have been redressed makes complacency about the Charter a less troubling choice at this point. Under that view it follows, now the deep thinking on rights has been done and is in the past, that balancing rights and limits is a different exercise. The grand pronouncements give way to fine tuning and subtle interpretation. Deference to the legislatures is more standard when issues do not present conflicts in principle but sit, instead, in the margin of appreciation. Presenting differences of opinion that way may mean that reasonable limits will typically prevail over rights protection. Meanwhile, the legislatures have grown savvy over the years and gained confidence in their ability to Charter-proof statutes, legislating to the limits of Charter compliance without having to invoke section 33. Still, it is an open question whether the federal government's legislative agenda which disowns evidence-based policymaking - will provoke a resurgence of vigilance on questions of rights protection.

From the start, the Charter enjoyed immense support from courts, advocates and the public, but also had detractors and critics. Many who resisted the Charter remained voluble, and were joined by others who took up the cause of defending parliamentary tradition and democratic 
capacity from the accretion of power to the courts under the Charter. The Charter jurisprudence under the Dickson and Lamer administrations opened up new debates about institutional relations which challenged the legitimacy of review and the Court's power to speak on the compelling issues of the day. As the halcyon days of "dialogue" showed, the override's bluff did not have to be called for section 33 to affect institutional relations. ${ }^{101}$ If the Court was determined not to provoke its use, the legislatures were almost as averse to enacting laws, notwithstanding the Charter. Yet it has psychological effects, and the override - together with other structural elements - exert a gravitational pull back to the middle. ${ }^{102}$ That pull is embedded in the history of the Charter and the structural indecision of that critical moment, when constitutional rights and parliamentary supremacy were partnered in the same document. Late in 1981, the choice was between a middle-ground Charter and no Charter at all.

As a matter of text, the balance between rights enforcement and democratic limits - sections 33 and 1's offsets to constitutional, judicial, and rights supremacy - is the Charter's hallmark, its professed genius. ${ }^{103}$ Discovering that middle ground is Canada's proclamation, its boast, to the world of constitutionalism. ${ }^{104}$ The academic community has invoked that genius to promote a view of the Charter as a template or model for other experiments in transformative constitutionalism. Some of the jurisdictions that adopted bills of rights after 1982 even improved on the Charter, with further corrections in favour of parliamentary supremacy

101 See generally P. Hogg \& A. Bushell, "The Charter Dialogue Between Courts and Legislatures (Or Perhaps The Charter of Rights Isn't Such a Bad Thing After All)" (1997) 35 Osgoode Hall L.J. 1; P. Hogg, A. Bushell Thornton \& W. Wright, "Charter Dialogue Revisited - Or "Much Ado About Metaphors"' (2007) 45 Osgoode Hall L.J. 1; (2007) 45 Osgoode Hall L.J., Charter Dialogue: Ten Years Later (special issues); and K. Roach, The Supreme Court on Trial: Judicial Activism or Democratic Dialogue (Toronto: Irwin Law Inc., 2001).

${ }_{102}$ See J. Cameron, "The Charter's Legislative Override: Feat or Figment of the Constitutional Imagination?" in I. Brodie \& G. Huscroft, eds., Constitutionalism in the Charter Era (Markham, ON: LexisNexis Canada, 2004) (examining the override's history and making that argument).

${ }_{103}$ See generally B. Berger \& J. Cameron, eds., "Rights Constitutionalism and the Canadian Charter of Rights and Freedoms" (2013) 50 Osgoode Hall L.J. (special issue).

${ }_{104}$ Parliamentary and judicial supremacy were traditionally thought of as incompatible opposites. As Marshall C.J. explained, in rationalizing judicial review in Marbury v. Madison, 1 Cranch 137, at 175 (1803), "[t]he constitution is either a superior paramount law, unchangeable by ordinary means, or it is on a level with ordinary legislative acts, and, like other acts, is alterable when the legislature shall please to alter it". "Between these alternatives", he pronounced, "there is no middle ground." 
and mechanisms to support democratic capacity. ${ }^{105}$ In this way, Canada is credited with leading the way in the move to a middle ground between parliamentary supremacy and constitutional or judicial supremacy. ${ }^{106}$

If that is our contribution to rights constitutionalism, the question it raises for Canada today is whether there can be too much middle ground. The embedded structures of equilibrium, compromise, and balance may cramp the Charter's entitlements and stunt its growth in today's posttransformational iteration of rights protection. From that frame of reference, it is worth asking whether the features we celebrate and export to others have made us cautious, to a fault. And it is also worth asking whether the Charter is in a space today that speaks too much the language of caution. At the same time, the compromises that gave birth to the Charter may argue, with merit, that the middle ground - defined by an organic relationship between rights and limits - is the Charter's destiny. In this view, the structural partnership of rights and limits, and institutional dialogue meets the expectations of legal and political culture, and suits a constitutional tradition that values balance over rigid principle and ideological choice. That perspective casts the early period of transformational energy in a different light, making it the exception, rather than the norm, in Charter narrative.

The purpose of this review has been to demonstrate that the "big" Charter issues are alive, both at the level of decision-making on cases that present themselves annually to the Court, and at the deeper level of reflecting on and mapping the Charter's place in legal and political culture. In simple terms, it is a matter of seeing those issues and being open to discussion and debate about the challenges they raise. What is troubling and disappointing is the McLachlin Court's yeoman-like jurisprudence, and its failure to seize the moment, in the Charter's 30th anniversary year, to see the "big" and speak in any profound way of the Charter's promises.

\footnotetext{
105 See J. Hiebert, "New Constitutional Ideas: Can Parliamentary Models Resist Judicial Dominance When Interpreting Rights?" (2004) 82 Texas L. Rev. 1963 and "Parliamentary Bills of Rights" (2006) 69 Mod. L. Rev. 7 (explaining the Charter's role in promoting the emergence of a "parliamentary rights model" in countries such as New Zealand, the United Kingdom and now some Australian states).

106 See Law \& Versteeg, supra, note 2, at 809-23 (discussing Canada's constitutional influence, under the heading, Is Canada a Constitutional Superpower?).
} 
